\section{Season and Explant Origin Affect Phenolic Content, Browning of Explants, and Micropropagation of $\times$ Malosorbus florentina (Zucc.) Browicz}

\author{
Aekaterini N. Martini and Maria Papafotiou ${ }^{1}$ \\ Laboratory of Floriculture and Landscape Architecture, Agricultural \\ University of Athens, Crop Science, 75 lera Odos, Athens, 118 55, Greece
}

Stavros N. Vemmos

Laboratory of Pomology, Department of Crop Science, Agricultural University of Athens, Iera Odos 75, 11855 Athens, Greece

Additional index words. in vitro propagation, adult and juvenile explant, explant location, subculture, rooting, acclimatization, endangered species

\begin{abstract}
The aim of this study was to develop an efficient protocol for in vitro propagation of the rare and endangered $\times$ Malosorbus florentina, not only enabling conservation of the species, but also its use as an ornamental. Explants excised from adult plants, shoot tip explants, and explants collected in March and April showed more browning and had higher content of total phenolics than explants excised from juvenile tissue, nodal explants, and those collected during any of the other months of the year. Shoot tip explants from adult plants were more difficult to establish in vitro (14\%) compared with explants from micropropagated plantlets or sprouts of burned plants $(29 \%$ to $36 \%)$. Nodal explants excised from seedlings were established at the highest percentage $(83 \%)$, giving the most shoots per explant (5.2). Generally, in vitro cultures established from adult plants, with the exception of one culture, showed lower multiplication rates compared with cultures from juvenile plants. Nodal explants from the base of sprouts produced a higher percentage $(60 \%)$ of shoots than explants from upper locations (20\% to $31 \%)$, but any differences in proliferation rates of established cultures ceased after the third subculture. Microshoots from juvenile cultures were more capable of rooting $(51 \%$ to $58 \%)$ than were those from adult plants $(16 \%$ to $32 \%)$, whereas $83 \%$ of the plantlets were acclimatized ex vitro independently of their origin, but plantlets of juvenile origin, although developing the same height as those originating from adult plants, had shorter internodes and thus more compact shape.
\end{abstract}

$\times$ Malosorbus florentina (Rosaceae) is a rare and endangered native species of Greece, which is considered a natural intergeneric hybrid of Malus sylvestris and Sorbus torminalis and occurs in a few localities, mostly as single trees or small groups of trees in forests with Abies and Pinus (Christensen, 1995). It is also found further north in the Balkan Peninsula, Italy, and northern Turkey (Browicz, 1983), whereas in Serbia, it is on the list of endangered to vulnerable plants (Tomović et al., 2003). Its largest populations in Greece, found in Mt. Parnitha National Park, were burned by a devastating fire in 2007 and their natural

Received for publication 6 Aug. 2012. Accepted for publication 26 Nov. 2012.

This project was carried out during Aekaterini Martini's Ph.D. studies financed by the Greek State Scholarships Foundation for the first two years.

${ }^{1}$ To whom reprint requests should be addressed; e-mailmpapaf@aua.gr. as a result of their genetic stability (Fay, 1994; Sarasan et al., 2006).

There is a report on establishment of in vitro cultures of $\times M$. florentina from seeds but the microshoots produced failed to form roots (Savić et al., 2006). However, at least in the population of $\times M$. florentina on Mt. Parnitha, it is difficult to find seeds because either plants do not produce fruits or fruits produced do not contain seeds (personal observations between 2004 and 2011). Apart from seeds, in vitro cultures of $\times M$. florentina have also been initiated from apical buds of adult plants, albeit with a very low percentage of culture establishment $(7 \%)$ as a result of contamination problems and explant browning that lead to death of explants (Papafotiou and Martini, 2009a, 2009b). The multiplication of microshoots was successful (Papafotiou and Martini, 2009a, 2009b), but their rooting ability was low (Martini and Papafotiou, 2009). Thus, to develop an efficient micropropagation protocol for $\times M$. florentina, the problem of contamination, explant browning, and low microshoot rooting ability should be addressed.

Browning and necrosis is a common problem in cultures of woody species and have been generally attributed to the oxidation of phenolic compounds in explant tissues (Dobránszki and Teixeira da Silva, 2010; Hu and Wang, 1983). Explants from axillary shoot tips of Vitis vinifera had a higher survival rate than those from terminal positions, and a strong negative correlation was found between survival in vitro and the pre-existing phenolic content of the explants (Yu and Meredith, 1986). Shoot tip explants of 'Koroneiki' olive trees exhibited higher browning rates together with higher total phenol and polyphenoloxidase activity compared with single-node explants, whereas explants derived from glasshouse-growing trees presented higher survival rates and lower total phenol and polyphenoloxidase activity than corresponding explants from field-growing trees (Roussos and Pontikis, 2001a, 2001b). The season of collection has been reported to affect browning of explants (Dobránszki et al., 2000; Modgil et al., 1999; Wang et al., 1994) as well as their survival through effects on the concentration of phenolics (Thomas and Ravindra, 1997). In addition, the season of explant collection has been found to affect the survival of explants through effects on microbial contamination (Thomas and Ravindra, 1997).

The present study investigated the effect of explant origin (juvenile, adult), explant location on shoots (apical, axillary), and season of explant collection on contamination and explant browning as well as on all stages of in vitro propagation of $\times M$. florentina, including microshoot rooting and acclimatization. The phenolic content of explants was also determined to correlate it with browning, which has been found to affect explant survival during in vitro culture establishment (Papafotiou and Martini, 2009a, 2009b). 


\section{Materials and Methods}

Explant origin. In vitro cultures of $\times$ M. florentina Zucc. were established from shoot explants, 0.8 to $1.0 \mathrm{~cm}$ long, with one (usually) or two buds collected from adult plants, sprouts of burned plants, micropropagated plantlets, and seedlings. Shoot tips from long shoots and spurs of various adult plants growing wild on Mt. Parnitha were collected in Mar. 2004, 2009, and 2010 and every month from Feb. 2006 to Mar. 2007, whereas both shoot tips and nodal segments were collected monthly from May 2009 to Aug. 2009 from one adult plant, which had survived the 2007 fire. From sprouts of plants that were burned in the 2007 fire at Mt. Parnitha, shoot tips and nodal segments were collected in May, June, and July 2009 as well as in Mar. 2010. The explants collected in June and July 2009 were distinguished regarding their location on stems into apical (shoot tip explants), top, middle, and basal, and these records were kept until the fourth subculture. Also, nodal explants were excised in July 2010 from the middle part of the stem of five- or eight-month-old plantlets grown in the field of the Agricultural University of Athens, which were produced from in vitro cultures established from sprouts of burned plants. From these plantlets, apical and nodal explants were excised once more, in July 2010, from 20d-old shoots that sprouted after the pruning for the first explant collection. Finally, explants, $0.5 \mathrm{~cm}$ long, were excised from 7-week-old seedlings (two explants from each seedling) grown in vitro from seeds collected in Fall 2009 (very few seeds were found) from one unburned plant on Mt. Parnitha. The seeds were sown on solid half-strength Murashige and Skoog (MS) medium with $2 \%(\mathrm{w} / \mathrm{v})$ sucrose, placed for cold stratification at $4{ }^{\circ} \mathrm{C}$ for three months, and then incubated at $25^{\circ} \mathrm{C}$ for germination and seedling growth.

Sterilization method. Shoot explants, collected from adult plants, sprouts, and micropropagated plantlets, were washed under running tap water for $10 \mathrm{~min}$, dipped in $90 \%$ ethanol for $10 \mathrm{~s}$, washed again, dipped in water solution of ascorbic acid (AA) and citric acid (CA) $\left(150 \mathrm{mg} \cdot \mathrm{L}^{-1}\right.$ each) for $30 \mathrm{~min}$, and surface-sterilized by $30 \%(\mathrm{v} / \mathrm{v})$ commercial bleach $(4.6 \% \mathrm{w} / \mathrm{v}$ sodium hypochlorite) solution with a few drops of Tween 20 for $10 \mathrm{~min}$. Explants collected from September to March were surface-sterilized using a lower concentration of commercial bleach solution, $15 \%$ or $20 \%(\mathrm{v} / \mathrm{v})$, because they were devoid of external bud scales and bark to reduce possible infections. Four 3-min rinses with sterile distilled water containing AA and CA $\left(150 \mathrm{mg} \cdot \mathrm{L}^{-1}\right.$ each) followed as well as one more rinse just before planting the explants to remove diffused phenolic compounds.

Seeds were separated from fruit flesh, washed thoroughly under running tap water, surface-sterilized by $10 \%(\mathrm{v} / \mathrm{v})$ commercial bleach solution for $10 \mathrm{~min}$, followed by four 3-min rinses with sterile distilled water.
Initial culture. Explants were cultured individually in test tubes $(25 \times 100 \mathrm{~mm})$ containing MS medium (Murashige and Skoog, 1962) with 3\% (w/v) sucrose supplemented with $1.0 \mathrm{mg} \cdot \mathrm{L}^{-1}$ benzyladenine and $0.1 \mathrm{mg} \cdot \mathrm{L}^{-1}$ indole-3-butyric acid (IBA) (basal medium) followed by transfer to fresh basal medium after $2 \mathrm{~d}$ culture to reduce their exposure to diffused phenolics. Explants from micropropagated plantlets and those from seedlings were not transferred to fresh medium because they exhibited low diffusion of phenolics.

All media were solidified with $0.8 \%(\mathrm{w} / \mathrm{v})$ agar and their $\mathrm{pH}$ was adjusted to 5.7 before autoclaving at $121{ }^{\circ} \mathrm{C}$ for $20 \mathrm{~min}$. Cultures were incubated in a growth chamber at $25^{\circ} \mathrm{C}$ and $16-\mathrm{h}$ photoperiod at $37.5 \mu \mathrm{mol} \cdot \mathrm{m}^{-2} \cdot \mathrm{s}^{-1}$ provided by cool-white fluorescent lamps.

Subcultures. Nodal explants, $0.5 \mathrm{~cm}$ long, excised from microshoots produced from in vitro established cultures were subcultured several times in the basal medium. Explants excised from seedlings were also cultured in the basal medium supplemented with $0.5 \mathrm{mg} \cdot \mathrm{L}^{-1}$ gibberellic acid $\left(\mathrm{GA}_{3}\right)$ to increase the height of microshoots produced. The subcultures took place in 75-mL glass vessels covered with plastic wrap (SANITAS, Sarantis S.A., Greece). Each subculture lasted 6 weeks.

Rooting and acclimatization. For root induction, microshoots, 1.0 to $2.0 \mathrm{~cm}$ long, were put in $145-\mathrm{mL}$ glass vessels covered with magenta caps on half-strength MS medium with $2 \%(\mathrm{w} / \mathrm{v})$ sucrose supplemented with $0.5 \mathrm{mg} \cdot \mathrm{L}^{-1} \mathrm{IBA}$ and $8.0 \mathrm{mg} \cdot \mathrm{L}^{-1}$ indole acetic acid for 1 week followed by 3 weeks' culture on half-strength MS with $2 \%$ $(w / v)$ sucrose, without plant growth regulators, for root elongation. This rooting technique has been found to improve rooting percentage in a previous study (Martini and Papafotiou, 2009).

For acclimatization, plantlets from adult plants or sprouts of burned plants with welldeveloped roots were transferred ex vitro to $500-\mathrm{mL}$ plastic containers on a mixture of peat-perlite $(1: 1 \mathrm{v} / \mathrm{v}$, eight plantlets per container). The containers were covered with plastic wrap (SANITAS) to reduce water loss for the first $7 \mathrm{~d}$ and placed in a growth chamber for 1 week at $20{ }^{\circ} \mathrm{C}$ under a 16 -h photoperiod at $37.5 \mu \mathrm{mol} \cdot \mathrm{m}^{-1} \cdot \mathrm{s}^{-1}$ provided by cool-white fluorescent lamps before being transferred to a heated glasshouse. Plantlets were watered twice a week and fertilized biweekly with $1 \mathrm{~g} \cdot \mathrm{L}^{-1}$ of a complete watersoluble fertilizer (Nutrileaf $60,20 \mathrm{~N}-20 \mathrm{P}$ 20K; Miller Chemical and Fertilizer Corp., Hanover, PA). Acclimatization measurements were taken after 22 weeks.

Measurement of explant browning and extraction and determination of phenolic compounds. Observations on the browning of explants were made on the second day of in vitro establishment before their transfer to fresh medium. Explants exhibiting intense brown discoloration and releasing phenolics into the medium were recorded as browning. To determine explant total phenolic content in and correlate it with browning, more than
20 explants from each stem location (apical, top, middle, base) and origin (adult plants, sprouts, micropropagated plantlets) were collected during April to May, June to July, and November, indicative of the periods when explants exhibited intense, low, and minimum browning, respectively. Explants were lyophilized and grounded into a fine powder by a centrifugal mill. Phenolic compounds were extracted from $50 \mathrm{mg}$ of this powder with $5 \mathrm{~mL}$ methanol high-performance liquid chromatography $100 \%$ in an ultrasonic ice bath for 10 min followed by centrifugation at $4000 \times g$ for $6 \mathrm{~min}$. The supernatant was kept and this procedure was repeated three more times for each sample to extract the majority of phenolics so that the final volume of extraction was $20 \mathrm{~mL}$.

Colorimetric determination of total phenols was based on the procedure of FolinCiocalteau as described by Waterman and Mole (1994) and results were expressed as $\mathrm{mg}$ (gallic acid equivalents). $\mathrm{g}^{-1}$ dry weight. Briefly, $50 \mu \mathrm{L}$ of the supernatant was added to $3.75 \mathrm{~mL}$ water and agitated thoroughly. Thereafter, $250 \mu \mathrm{L}$ of Folin reagent and $750 \mu \mathrm{L}$ of saturated $\mathrm{Na}_{2} \mathrm{CO}_{3}$ were added and thoroughly mixed. The mixture was left to stand at room temperature for $2 \mathrm{~h}$ and the absorbance with a spectrophotometer at $760 \mathrm{~nm}$ was measured against a reagent blank.

Statistical analysis. The complete randomized design was used. The significance of the results was tested by one-way analysis of variance and the means of the treatments were compared by the Tukey-Kramer honestly significant difference at $P=0.05$ (JMP software, SAS Institute, Cary, NC). The number of replicates per treatment is reported in each data table or figure. In the phase of culture initiation, the number of replicates per treatment varied depending on the availability of stock plant tissue and contamination. Subcultures and rooting experiments were repeated many times and the results were pooled for the statistical analysis, leading to a different number of replicates per treatment.

\section{Results and Discussion}

Our previous work indicated the appropriate growth medium for establishment of in vitro culture and shoot proliferation of $\times$ M. florentina (Papafotiou and Martini, 2009a, 2009b), which was used in the present study, highlighting simultaneously the problem of contamination and explant browning that prevents the successful establishment of explants at the initiation phase of in vitro culture. Although the establishment of in vitro cultures was feasible from explants of all origins in the present work, its success depended on the efficacy of explants sterilization and the inhibition of phenolinduced browning of explants.

At establishment of in vitro cultures from adult plants, contamination was better controlled from April to August (contamination percentage $17 \%$ to $54 \%$ ), whereas during 
winter months, surface sterilization was highly ineffective (contamination percentage $63 \%$ to $99 \%$ ), although external scales of the bud were removed along with bark to reduce the disease load of the explant. Similarly, the contamination percentage of explants from sprouts was lower from May to July (11\% to $27 \%$ ) than in March (74\%). Explants excised in June from the middle of the stem of five- or eight-month-old micropropagated plantlets were infected at a higher percentage $(72 \%)$ than apical explants and explants excised from the top of 20-d-old shoots sprouted on these plantlets after pruning (9\%). So, contamination was better controlled collecting explants from the new vegetation from April to August. The season of explant collection has been reported to affect the survival of mango explants by affecting microbial contamination (Thomas and Ravindra, 1997). The high contamination of explants collected during winter months could be attributed to the fact that many pathogens overwinter inside the buds, whereas they infect other organs during spring and summer (Holb et al., 2004). Moreover, bud surface sterilization was most probably hindered by the dense hairs of $\times M$. florentina buds. Seeds placed on nutrient medium to germinate were infected at $43 \%$.

Successful introduction to culture of a large number of threatened plants has been hampered by exudation of toxic materials from cut surfaces of the explant (Sarasan et al., 2006). Several methods have been developed for preventing or controlling explant browning such as treatments of the mother plant (darkening or heat treatment), direct treatments of explants during culture initiation (pretreatment with antioxidants, cold or dark treatment), supplementing the initial medium with different additives to prevent production of phenolics or remove inhibitory phenolic substances (Dobránszki and Teixeira da Silva, 2010), use of smaller explants, which produce less phenolics (Kaushal et al., 2005), or frequent subculture to fresh medium (Hu and Wang, 1983).

In this study, the release of phenolics into the medium and the browning of explants were more intense in March and April, whereas they steadily declined after June, so that in winter, they were not observed at all. Pretreatment of explants with antioxidants, with an extra rinse just before planting and transfer to fresh medium, partially controlled explant and medium browning, but this problem continued. Explants from adult plants released phenolics into the medium at a higher percentage (61\%) than did juvenile explants from sprouts or micropropagated plantlets $(30 \%)$, whereas the percentage phenolic diffusion of apical explants was generally higher $(60 \%)$ than that of explants from lower positions (32\%). The content of apical explants in total phenolics was also found to be higher than that of explants from lower locations (Fig. 1A), whereas explants from micropropagated plantlets, grown in the field, contained less total phenolics compared with explants from adult plants or sprouts grown wild (Fig. 1B). The season of explant collection also affected their total phenolic content because explants collected in April and May contained more phenolics than those collected in June and July, and explants collected in November contained the least phenolics (Fig. 1C), confirming observations mentioned previously on seasonal variations of browning of explants from adult plants. Season of explant collection has been reported to affect the browning of apple shoot tip explants (Dobránszki et al., 2000; Modgil et al., 1999; Wang et al., 1994) as well as the survival of mango explants because of lower phenolic content (Thomas and Ravindra, 1997). Similar to the present work, shoot tip explants of 'Koroneiki' olive trees exhibited higher browning rates and total phenol and polyphenoloxidase activity compared with nodal explants, whereas explants derived from glasshouse-growing trees had higher survival rates and lower browning rates and total phenol concentrations than the corresponding explants from field-growing trees (Roussos and Pontikis, 2001a, 2001b). Although explants from adult $\times$ M. florentina plants presented more intense browning than explants from sprouts, they did not differ significantly in their content of total phenols. Possibly, explants from adult and juvenile origin differed in the composition of phenolic compounds or the polyphenoloxidase activity and therefore suffered different degrees of oxidation. Browning rates of 'Koroneiki' olive trees explants are not influenced significantly by season, whereas the activity of oxidative enzymes is (Roussos and Pontikis, 2001a, 2001b).

Explant establishment was generally low when explants came from adult or juvenile plants (Table 1). Despite the difficulty in finding seeds, nodal explants from seedlings were established at a high percentage (Table 1 ), in agreement with earlier work on the species (Savić et al., 2006), as well as on the congener $S$. domestica (Arrillaga et al., 1991). In vitro cultures from adult plants were established mainly in March and August with difficulty. Explants from sprouts collected in May formed only callus. A similar response was also found previously for explants excised from adult plants (Papafotiou and Martini, 2009b). The bud sprouting percentage was higher in March $(64 \%)$ than in June and July (33\%). There are no data for August cultures of explants from sprouts because it was difficult to find sprouts in August because plants were completely browsed. In June and July, explants from the base of sprouts gave shoots at a higher percentage $(60 \%)$ than those from upper locations $(20 \%$ to $31 \%)$, whereas apical explants and explants excised from the top of sprouts gave longer shoots than those from the middle and base (Fig. 2B). Similarly to sprouts, the bud sprouting percentage of middle and top explants from micropropagated plantlets (56\% and $35 \%$, respectively) was higher compared with that of apical explants (15\%). Explants from seedlings gave more shoots per explant in the initial culture
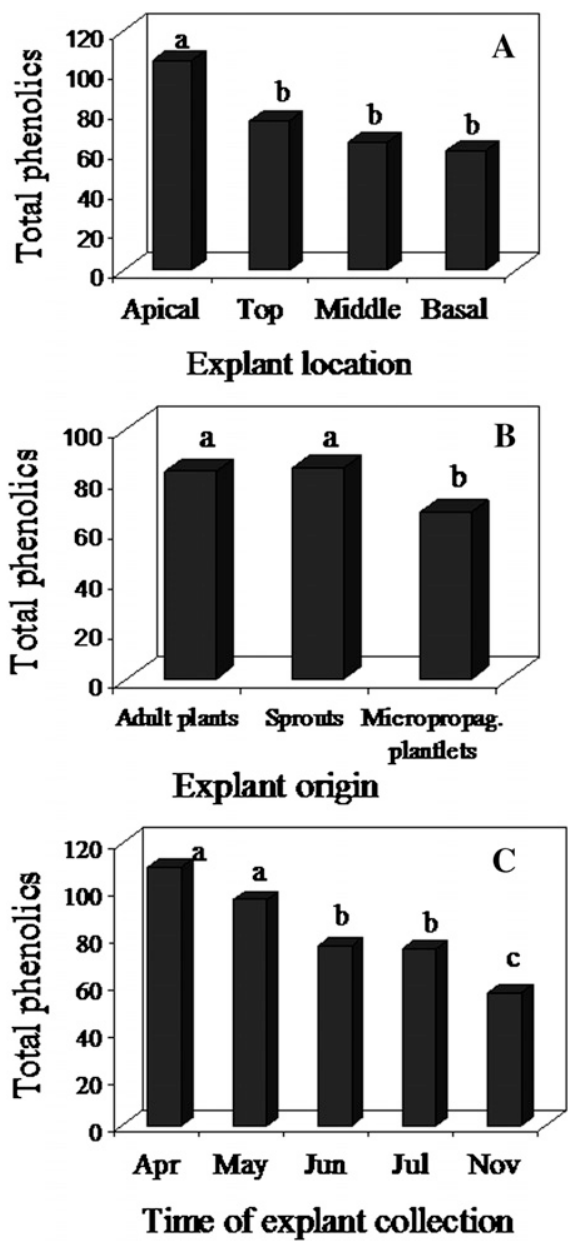

Fig. 1. Content of $\times M$. florentina explants in total phenolics (mg gallic acid equivalent/g dry weight) according to explant location (A), origin (B), and time of collection (C). Explants from adult plants and sprouts were collected in April, May, June, and November and explants from micropropagated plantlets in June, July, and November. Mean separation by TukeyKramer honestly significant difference at $P=$ $0.05, \mathrm{n}=20$ to 60 .

than did explants from adult plants or sprouts, whereas explants from micropropagated plantlets gave the longest shoots (Table 1).

Cultures established from adult plants, except for the culture of Mar. 2004, exhibited lower multiplication rates in subsequent subcultures than cultures from sprouts, micropropagated plantlets, or seedlings treated with $0.5 \mathrm{mg} \cdot \mathrm{L}^{-1} \mathrm{GA}_{3}$ (Table 1 ). The addition of $\mathrm{GA}_{3}$ to the basal culture medium in subcultures established from seedlings was necessary to obtain elongated shoots suitable for rooting, whereas the shoot number was increased simultaneously. In apple, the balance between $\mathrm{GA}_{3}$ and IBA was found to be important for shoot elongation (Yepes and Aldwinckle, 1994).

The explant location on sprouts affected the multiplication rates until the second subculture, whereas later the explant response to endogenous plant growth regulators was diminished (Fig. 2A-B). According to Marks and Myers (1992), culture initiation is arguably 
Table 1. Comparative response of adult and juvenile explants in initial culture and subcultures in MS with 1.0 BA/0.1 IBA (mg. $\mathrm{L}^{-1}$ ) of excised microshoots after 1week culture in half-strength MS with $0.5 \mathrm{IBA} / 8.0 \mathrm{IAA}\left(\mathrm{mg} \cdot \mathrm{L}^{-1}\right)$ and transfer in half-strength MS without plant growth regulators for 3 more weeks as well as in acclimatization of rooted plantlets in peat-perlite $1: 1(\mathrm{v} / \mathrm{v})$ after 22 weeks of ex vitro culture.

\begin{tabular}{|c|c|c|c|c|c|c|c|c|c|c|c|}
\hline \multirow[b]{2}{*}{ Explant origin } & \multicolumn{3}{|c|}{ Initial culture } & \multicolumn{2}{|c|}{ Subcultures } & \multicolumn{3}{|c|}{ Rooting } & \multicolumn{3}{|c|}{ Acclimatization } \\
\hline & $\begin{array}{c}\text { Established } \\
(\%)\end{array}$ & $\begin{array}{l}\text { Shoot } \\
\text { number }\end{array}$ & $\begin{array}{l}\text { Shoot } \\
\text { length } \\
(\mathrm{cm})\end{array}$ & $\begin{array}{l}\text { Shoot } \\
\text { number }\end{array}$ & $\begin{array}{l}\text { Shoot } \\
\text { length } \\
(\mathrm{cm})\end{array}$ & $\begin{array}{l}\text { Rooting } \\
\quad(\%)\end{array}$ & $\begin{array}{c}\text { Root } \\
\text { number }\end{array}$ & $\begin{array}{l}\text { Root } \\
\text { length } \\
(\mathrm{cm})\end{array}$ & $\begin{array}{c}\text { Acclimated } \\
(\%)\end{array}$ & $\begin{array}{l}\text { Plantlet } \\
\text { ht }(\mathrm{cm})\end{array}$ & $\begin{array}{c}\text { Number of } \\
\text { nodes }\end{array}$ \\
\hline $\begin{array}{l}\text { Adult plant-Mar. } \\
2004 \text { (high } \\
\text { multiplication rate) }\end{array}$ & $\begin{array}{c}33.3 \\
(n=6)\end{array}$ & $1.5 \mathrm{abc}$ & $0.4 \mathrm{ab}$ & $\begin{array}{c}6.3 \mathrm{a} \\
(\mathrm{n}=433)\end{array}$ & $0.6 \mathrm{~b}$ & $\begin{array}{c}31.7 \\
(n=205)\end{array}$ & $2.1 \mathrm{~b}$ & $3.6 \mathrm{a}$ & $\begin{array}{c}83.3 \\
(n=12)\end{array}$ & $29.1 \mathrm{a}$ & $25.9 \mathrm{~b}$ \\
\hline $\begin{array}{l}\text { Adult plants (low } \\
\text { multiplication rates) }\end{array}$ & $\begin{array}{c}14.2 \\
(\mathrm{n}=176)\end{array}$ & $1.3 \mathrm{c}$ & $0.5 \mathrm{~b}$ & $\begin{array}{c}1.8 \mathrm{e} \\
(\mathrm{n}=227)\end{array}$ & $0.6 \mathrm{~b}$ & $\begin{array}{c}15.8 \\
(\mathrm{n}=114)\end{array}$ & $1.4 \mathrm{~b}$ & $4.4 \mathrm{a}$ & - & - & - \\
\hline $\begin{array}{l}\text { Sprouts of burned } \\
\text { plants }\end{array}$ & $\begin{array}{c}36.1 \\
(\mathrm{n}=241)\end{array}$ & $2.0 \mathrm{bc}$ & $0.6 \mathrm{~b}$ & $\begin{array}{c}4.1 \mathrm{~b} \\
(\mathrm{n}=1503)\end{array}$ & $1.0 \mathrm{a}$ & $\begin{array}{c}51.3 \\
(\mathrm{n}=489)\end{array}$ & $3.2 \mathrm{a}$ & $2.5 \mathrm{~b}$ & $\begin{array}{c}83.3 \\
(n=24)\end{array}$ & $28.8 \mathrm{a}$ & $34.6 \mathrm{a}$ \\
\hline $\begin{array}{l}\text { Micropropagated } \\
\text { plantlets }\end{array}$ & $\begin{array}{c}28.9 \\
(\mathrm{n}=38)\end{array}$ & $3.1 \mathrm{ab}$ & $1.2 \mathrm{a}$ & $\begin{array}{c}2.6 \mathrm{~cd} \\
(\mathrm{n}=56)\end{array}$ & $1.0 \mathrm{a}$ & $\begin{array}{c}51.2 \\
(n=43)\end{array}$ & $2.7 \mathrm{ab}$ & $1.8 \mathrm{~b}$ & - & - & - \\
\hline Seedlings & $\begin{array}{c}83.3 \\
(n=6)\end{array}$ & $5.2 \mathrm{a}$ & $0.7 \mathrm{ab}$ & $\begin{array}{l}2.3 \mathrm{de} \\
(\mathrm{n}=60)\end{array}$ & $0.5 \mathrm{~b}$ & - & - & - & - & - & - \\
\hline Seedlings $+0.5 \mathrm{GA}_{3}$ & - & - & - & $\begin{array}{c}3.6 \mathrm{bc} \\
(\mathrm{n}=60)\end{array}$ & $0.8 \mathrm{a}$ & $\begin{array}{c}57.7 \\
(\mathrm{n}=26)\end{array}$ & $3.3 \mathrm{ab}$ & $1.3 \mathrm{~b}$ & - & - & - \\
\hline
\end{tabular}

Mean separation in columns by Tukey-Kramer honestly significant difference at $P=0.05$.

$\mathrm{MS}=$ Murashige and Skoog; BA = benzyladenine; IBA = indole-3-butyric acid; IAA = indole acetic acid; GA = gibberellic acid.
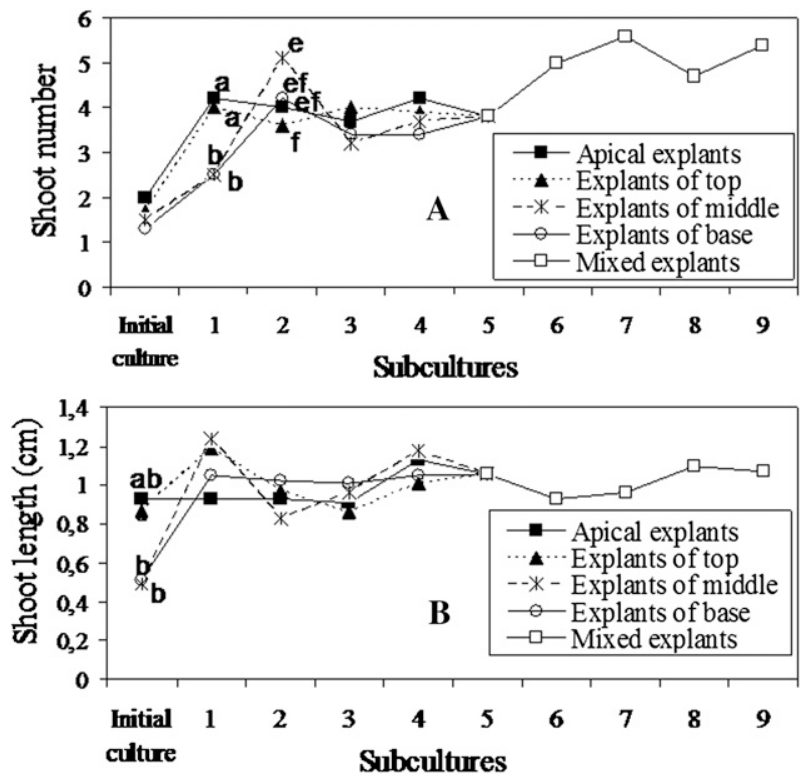

Fig. 2. Mean number (A) and mean length (B) of shoots produced during initial culture of explants collected from sprouts of burned plants in June and July 2009 from marked locations and subcultures in Murashige and Skoog medium with $1.0 \mathrm{mg} \cdot \mathrm{L}^{-1}$ benzyladenine (BA) and $0.1 \mathrm{mg} \cdot \mathrm{L}^{-1}$ indole-3-butyric acid (IBA) (after the fourth subculture, explants from various locations were mixed). Mean separation in each culture by Tukey-Kramer honestly significant difference at $P=0.05, \mathrm{n}=$ four to 28 in initial culture, $\mathrm{n}=18$ to 84 in subcultures.

the most critical stage of micropropagation because the potential for multiple shoot generation lies within single buds. They also found that an explant's location along a growing shoot as well as the location of that shoot on the stock plant determined their developmental potential in vitro. Hence, predetermined growth from apical and axillary buds could still be expressed in culture despite their separation at culture initiation and the application of plant growth regulators that broke their interaction.

Although the culture of Mar. 2004 was initiated from an adult plant, it gave the highest number of shoots per explant in the subcultures, but these shoots were shorter compared with those of juvenile cultures
(Table 1). Explants of the Mar. 2004 culture formed two to three long and many short shoots, the latter resulting in the reduction of the mean shoot length. This culture was maintained successfully for almost 50 subsequent subcultures. The high multiplication rate of this culture compared with other cultures initiated from adult plants could be explained by the different degree of maturity of different parts of mature trees. Using explants from juvenile tissues, which are often at the basal parts of mature trees, in vitro propagation can be achieved. Explants taken from juvenile parts (epicormic shoots, lower branches, grafting) of mature trees of $S$. aucuparia exhibit higher multiplication rates and better rooting response than explants from mature parts (branches in top parts of crown) of trees (Chalupa, 1992, 2002), and explants from epicormic shoots of Quercus rubra formed on the basal zone of the trunk have a greater capacity for in vitro establishment than do explants from crown branches (Vieitez et al., 1993). Alternatively, micropropagation of adult plants could be facilitated using rejuvenation methods, which are supposed to return tissue explants from the mature to juvenile phase and include application of cytokinin either during or immediately after explants are placed in culture, serial grafting, propagation of stump sprouts, or severe pruning (Greenwood, 1987). Burning of adult plants of $\times M$. florentina on Mt. Parnitha led to their rejuvenation through the production of many sprouts from the trunk's base and roots.

Microcuttings from adult cultures had low rooting ability as was also found in our previous work (Martini and Papafotiou, 2009), whereas those from juvenile cultures rooted at higher percentages, although the rooting percentage did not exceed $58 \%$ (Table 1). Microcuttings from the culture of Mar. 2004 rooted at a higher percentage than those from other adult cultures. The ability of certain culture lines to root better than others could be attributed to the fact that they were derived from culture sources with higher growth rates (Marks and Myers, 1992). More roots were formed by microshoots from juvenile cultures, whereas their length was greater in microshoots from adult cultures (Table 1). Rooting failure of microshoots produced from cultures established from seedlings previously reported (Savić et al., 2006) was probably the result of lack of plant growth regulators in the rooting medium. Further improvement of rooting may be needed. The differences in rooting capacity between microcuttings derived from adult and juvenile stock plants may be related to differences in the hormone levels at the base of cuttings during the first days of the root inductive period. In Sequoia sempervirens, the difficult-to-root mature clone differs from 
the young clone in its auxin metabolism (Blažková et al., 1997), whereas differences between apple rootstocks M.26 and M.9 rooting responses may be related to differences in free IAA levels in the shoot base (Alvarez et al., 1989). Moreover, different levels of endogenous IAA and ABA were found to correspond to different rooting ability. Low IAA and high ABA were detected in hardwood cuttings of grapevine rootstocks having a low rooting rate, whereas high IAA and low ABA levels were detected in cuttings having a high rooting rate (Kelen and Ozkan, 2003). In microcuttings of 'Jonathan' apple, the IAA/ ABA ratio increased from 0.2 in difficult-toroot shoots from initial culture up to 0.7 in easy-to-root shoots from long-term subculture (Noiton et al., 1992).

Summarizing, most cultures derived from buds of adult plants of $\times M$. florentina were established with more difficulty, had lower multiplication rates in subcultures, and microshoots rooted at lower percentages compared with cultures from juvenile or rejuvenated tissue (seedlings, sprouts, micropropagated plantlets). The better response of young plants compared with adult in micropropagation is confirmed by many reports concerning other species such as Sorbus aucuparia and $S$. torminalis (Chalupa, 1992), S. domestica (Arrillaga et al., 1991), Malus sp. (Ur-Rahman et al., 2007), Quercus euboica (Kartsonas and Papafotiou, 2007), Acacia mangium (Monteuuis, 2004), Cupressus sempervirens (Capuana and Giannini, 1997), Taxus mairei (Chang et al., 2001), etc.

Plantlets from adult and juvenile $\times M$. florentina did not differ in acclimatization percentage and were easily established ex vitro at a high survival rate (Table 1), as has also been found for $S$. domestica (Arrillaga et al., 1991). Although plantlets from both origins did not differ in plant height after 22 weeks of ex vitro culture, those from sprouts formed more nodes than those from adult plants (Table 1), resulting in more compact plant shape, in agreement with results for Malus sp., in which glasshouse juvenile clones of apomictic Malus sp. have shorter internodes, a greater number of leaves, and more dry weight compared with their mature counterparts (Ur-Rahman et al., 2007).

Concluding, explant origin, location, and season of collection significantly affected the browning of explants, which constituted a serious problem during the establishment of in vitro cultures of $\times M$. florentina. Explant origin from adult or juvenile plant tissue was also crucial for the shoot proliferation rate of established cultures, the rooting ability of excised microshoots. and the morphology of the plantlets after acclimatization. The season of explant collection, apart from affecting contamination and browning, also had a direct effect on shoot production. Therefore. for an efficient micropropagation protocol for $\times M$. florentina, it is best to use nodal explants excised during summer months from juvenile or rejuvenated stock plants, which have the potential to establish at higher rates in vitro, proliferate and root more efficiently, and give compact plants.

\section{Literature Cited}

Alvarez, R., S.J. Nissen, and E.G. Sutter. 1989. Relationship between indole-3-acetic acid levels in apple (Malus pumila Mill) rootstocks cultured in vitro and adventitious root formation in the presence of indole-3-butyric acid. Plant Physiol. 89:439-443.

Arrillaga, I., T. Marzo, and J. Segura. 1991. Micropropagation of juvenile and adult Sorbus domestica L. Plant Cell. Tiss. Org. 27:341348.

Blažková, A., B. Sotta, H. Tranvan, R. Maldiney, M. Bonnet, J. Einhorn, L. Kerhoas, and E. Miginiac. 1997. Auxin metabolism and rooting in young and mature clones of Sequoia sempervirens. Physiol. Plant. 99:73-80.

Browicz, K. 1983. ×Malosorbus florentina (Zuccagni) Browicz (Rosaceae) in Greece. Ann. Musei Goulandris 6:27-35.

Capuana, M. and R. Giannini. 1997. Micropropagation of young and adult plants of cypress (Cupressus sempervirens L.). J. Hort. Sci. $72: 453-460$

Chalupa, V. 1992. Micropropagation of European mountain ash (Sorbus aucuparia L.) and wild service tree [Sorbus torminalis (L.) Cr.], p. 211-226. In: Bajaj, Y.P.S. (ed.). Biotechnology in agriculture and forestry 18. High-Tech and Micropropagation II. Springer-Verlag, Berlin, Germany.

Chalupa, V. 2002. In vitro propagation of mature trees of Sorbus aucuparia L and field performance of micropropagated trees. J. Forest Sci. 48:529-535.

Chang, S.H., C.K. Ho, Z.Z. Chen, and J.Y. Tsay. 2001. Micropropagation of Taxus mairei from mature trees. Plant Cell Rpt. 20:496-502.

Christensen, K.I. 1995. ×Malosorbus florentina (Zuccagni) Browicz, p. 358-359. In: Phitos, D., A. Strid, S. Snogerup, and W. Greuter (eds.). The red data book of rare and threatened plants of Greece. Financed by the World Wide Fund for Nature (WWF), K. Michalas S.A., Athens, Greece.

Dobránszki, J., A. Abdul-Kader, K. Magyar-Tábori, E. Jámbor-Benczúr, T. Bubán, J. Szalai, and J. Lazányi. 2000. In vitro shoot multiplication of apple: Comparative response of three rootstocks to cytokinins and auxin. Intl. J. Hort. Sci. 6:7678.

Dobránszki, J. and J.A. Teixeira da Silva. 2010. Micropropagation of apple-A review. Biotechnol. Adv. 28:462-488.

Fay, M.F. 1994. In what situations is in vitro culture appropriate to plant conservation? Biodivers. Conserv. 3:176-183.

Greenwood, M.S. 1987. Rejuvenation of forest trees. Plant Growth Regulat. 6:1-12.

Holb, I.J., B. Heijne, and M.J. Jeger. 2004. Overwintering of conidia of Venturia inaequalis and the contribution to early epidemics of apple scab. Plant Dis. 88:751-757.

Hu, C.Y. and P.G. Wang. 1983. Meristem, shoot tip and bud culture, p. 177-227. In: Evans, D.A., W.R. Sharp, P.V. Ammirato, Y. Yamada (eds.) Handbook of plant cell culture. Vol. 1. Macmillan, New York, NY.

Kartsonas, E. and M. Papafotiou. 2007. Mother plant age and seasonal influence on in vitro propagation of Quercus euboica Pap., an endemic, rare and endangered oak species of Greece. Plant Cell Tiss. Org. 90:111-116.

Kaushal, N., M. Modgil, M. Thakur, and D.R. Sharma. 2005. In vitro clonal multiplication of an apple rootstock by culture of shoot apices and axillary buds. Indian J. Exp. Biol. 43:561565.

Kelen, M. and G. Ozkan. 2003. Relationships between rooting ability and changes of endogenous IAA and ABA during rooting of hardwood cuttings of some grapevine rootstocks. European J. Hort. Sci. 68:8-13.

Marks, T.R. and P.E. Myers. 1992. Effect of explant location upon early culture development in vitro. J. Hort. Sci. 67:583-591.

Martini, A.N. and M. Papafotiou. 2009. In vitro rooting of $\times$ Malosorbus florentina Zucc. microshoots. Acta Hort. 813:491-496.

Modgil, M., D.R. Sharma, and S.V. Bhardwaj. 1999. Micropropagation of apple cv. Tydeman Early Worcester. Sci. Hort. 81:179188.

Monteuuis, O. 2004. In vitro micropropagation and rooting of Acacia magnium microshoots from juvenile and mature origins. In Vitro Cell. Dev. Biol. Plant 40:102-107.

Murashige, T. and F. Skoog. 1962. A revised medium for rapid growth and bioassays with tobacco tissue cultures. Physiol. Plant. 15:473497.

Noiton, D., J.H. Vine, and M.G. Mullins. 1992. Effects of serial subculture in vitro on the endogenous levels of indole-3-acetic acid and abscisic acid and rootability in microcuttings of 'Jonathan' apple. Plant Growth Regulat. 11:377-383.

Papafotiou, M. and A.N. Martini. 2009a. Effect of growth medium on in vitro regeneration of $\times$ Malosorbus florentina Zucc. Acta Hort. 813:497-501

Papafotiou, M. and A.N. Martini. 2009b. Effect of season and sterilization method on response of $\times$ Malosorbus florentina (Zucc.) Browicz (Rosaceae) buds to in vitro culture. Acta Hort. 813:503-508.

Roussos, P.A. and C.A. Pontikis. 2001a. Oxidative browning in 'Koroneiki' olive explants as influenced by oxidative enzyme activities and endogenous phenolic compounds. J. Hort. Sci. Biotechnol. 76:441-446.

Roussos, P.A. and C.A. Pontikis. 2001b. Phenolic compounds in olive explants and their contribution to browning during the establishment stage in vitro. Gartenbauwissenschaft. 66:298303.

Sarasan, V., R. Cripps, M.M. Ramsay, C. Atherton, M. McMichen, G. Prendercast, and J.K. Rowntree. 2006. Conservation in vitro of threatened plants-Progress in the past decade. In Vitro Cell. Dev. Biol. Plant 42:206-214.

Savić, J., M. Dević, Z. Giba, and D. Grubišić. 2006. In vitro propagation of endangered relic plant species Malosorbus florentina. International Scientific Conference Sustainable Use of Forest Ecosystems-The Challenge of the $21^{\text {st }}$ Century, 8-10 Nov. 2006, Donji Milanovac, Serbia. Summary. p. 529 533.

Thomas, P. and M.B. Ravindra. 1997. Shoot tip culture in mango: Influence of medium, genotype, explants factors, season and decontamination treatments on phenolic exudation, explants survival and axenic culture establishment. J. Hort. Sci. 72:713-722.

Tomović, G., M.B. Niketić, and V. Stevanović. 2003. Malosorbus florentina (RosaceaeMaloideae)-Distribution, synecology and threatened status in Serbia. Phyton-annales rei botanicae 43:295-306.

Ur-Rahman, H., D.J. James, P.D.S. Caligari, and A. Wetten. 2007. Difference in competence for in vitro proliferation and ex vitro growth of 
genetically identical mature and juvenile clones of apomictic Malus species. Pak. J. Bot. 39:1197-1206.

Vieitez, A.M., F. Pintos, M.C. San-José, and A. Ballester. 1993. In vitro shoot proliferation determined by explants orientation of juvenile and mature Quercus rubra L. Tree Physiol. 12:107-117.
Wang, Q.C., H.R. Tang, Y. Quan, and G.G. Zhou. 1994. Phenol induced browning and establishment of shoot-tip explants of 'Fuji' apple and 'Jinhua' pear cultured in vitro. J. Hort. Sci. 69:833-839.

Waterman, P.G. and S. Mole. 1994. Analysis of phenolic plant metabolites. Bluckwell Scientific Publications, Oxford, London, UK. p. 238.
Yepes, L.M. and H.S. Aldwinckle. 1994. Micropropagation of thirteen Malus cultivars and rootstocks, and effect of antibiotics on proliferation. Plant Growth Regulat. 15:55-67.

Yu, D. and C.P. Meredith. 1986. The influence of explant origin on tissue browning and shoot production in shoot tip cultures of grapevine. J. Amer. Soc. Hort. Sci. 111:972-975. 